\title{
POTENSI IKAN Osteochilus hasselti SEBAGAI BAHAN BAKU LOKAL UNTUK PAKAN DALAM KEGIATAN BUDIDAYA IKAN DI DANAU RANO
}

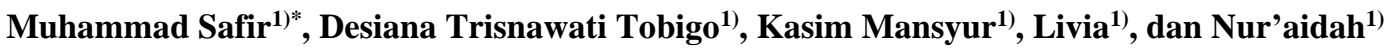 \\ ${ }^{1}$ Fakultas Peternakan dan Perikanan Universitas Tadulako \\ J1. Soekarno Hatta KM 9 Palu, Sulawesi Tengah, Indonesia \\ Email : Safirmuhammad@gmail.com
}

\begin{abstract}
Lake Rano has abundant water resources, one of which is Nilem fish (Osteochilus hasselti). However, the abundance of Nilem (O. hasselti) has not been appropriately utilized and has become a pest in the local community's fishery activities. This study aimed to examine the potential of Nilem (O. hasselti) in terms of nutrient content as a local raw material in making the fish feed to support fish farming activities in Lake Rano. The method in conducting the research was initiated by taking samples of Nilem fish directly from the waters of Lake Rano, then drying the whole fish (without cleaning), and mashing it. Furthermore, testing the nutrient content of fish meal as a test sample. The analysis showed that the whole Nilem fish meal had a protein content of $39.62 \%$, a fat content of $1.4 \%$, a carbohydrate content of $31.7 \%$, an ash content of $17.9 \%$, and a moisture content of $9.38 \%$. It can be concluded that Nilem fish (O. hasselti) has the potential to be used as a substitute for the primary raw material as a source of animal protein for making fish feed, especially in Lake Rano.
\end{abstract}

Keywords: Nilem (Osteochilus hasselti), Lake Rano, local feed, Central Sulawesi

\section{PENDAHULUAN}

Danau rano merupakan salah satu danau yang ada di Sulawesi Tengah. Tepatnya di Kabupaten Donggala, Kecamatan Balaesang Tanjung, Desa Rano Balaesang. Danau ini memiliki luas \pm 260 ha dengan kedalaman hingga 80 meter. Selain itu, danau Rano memiliki sumber daya perairan yang cukup melimpah seperti ikan mujair, ikan sidat, ikan gabus, ikan betok dan lainnya yang menjadi komoditas asli daerah tersebut. Suatu upaya yang dilakukan dalam mengelola dan memanfaatkan sumber daya perairan danau Rano secara berkelanjutan yaitu melalui penerapan aturan adat berupa pengaturan penggunaan alat tangkap ikan (ukuran mata jaring diperbolehkan minimal 3,5 cm), dan tidak diperbolehkan menggunakan perahu mesin dalam segala aktivitas di perairan danau (Paino, 2015).

Sumberdaya perairan danau Rano saat ini semakin melimpah lebih khusus dengan adanya beberapa ikan introduksi seperti, ikan Nila (Oreocromis niloticus), ikan Mas (Cyprinus caprio) dan ikan Nilem (Osteochilus hasselti) (Herjayanto et al.,
2019). Ikan tersebut merupakan hasil introduksi yang dilakukan oleh Pemerintah Kabupaten Donggala pada tahun 2003-2004 (Paino, 2015). Salah satu tujuan dari kegiatan introduksi adalah untuk mengendalikan populasi tanaman air yang mengalami peningkatan seperti eceng gondok dan kangkung (Umar dan Sulaiman 2013; Herjayanto et al. 2019). Meskipun demikian, pada sisi lain adanya ikan introduksi pada suatu perairan dapat menyebabkan berkurangnya populasi ikan asli sehingga hasil tangkapan ikan asli dari perairan tersebut menurun (Umar dan Sulaiman 2013). Salah satu penyebabnya adalah pertumbuhan dan perkembangan ikan introduksi yang relatif cepat sehingga akan mendominansi penguasaan ruang (Gani et al., 2015) seperti yang terjadi di perairan Danau Rano, dimana saat ini didominasi oleh ikan Nilem (O. hasselti).

Keberadaan ikan Nilem (O. hasselti) di perairan Danau Rano hingga saat ini belum dimanfaatkan dengan baik, terlebih masyarakat setempat tidak mengonsumsi ikan tersebut. Selain itu, ikan ini selalu 
KAUDERNI : Journal of Fisheries, Marine and Aquatic Science

https://jurnal.stplpalu.ac.id/index.php/kauderni/index

Volume 2, Nomor 2, (2020)

ISSN 2541-0571

https://doi.org/10.47384/kauderni.v2i2.44

mengganggu aktivitas perikanan masyarakat setempat seperti mengonsumsi umpan dalam perangkap ikan (bubu dan pancing), dan saat pemberian pakan dalam kegiatan budidaya ikan dalam keramba. Keberadaan ikan Nilem (O. hasselti) yang melimpah dan tidak termanfaatkan mendorong peneliti untuk mengkaji potensi ikan Nilem (O. hasselti) dari segi kandungan nutrien sebagai bahan baku lokal untuk pembuatan pakan ikan dalam mendukung kegiatan budidaya ikan pada perairan danau Rano.

\section{METODE PENELITIAN Waktu dan Tempat}

Penelitian dilaksanakan mulai pada bulan Mei hingga Juni 2020. Sampel ikan uji di peroleh dari perairan danau Rano, Desa Rano Balaesang, Kecamatan Balaesang Tanjung, Kabupaten Donggala, Sulawesi Tengah. Analisis kandungan nutrien bahan melalui uji proksimat dilakukan di laboratorium nutrisi pakan, Fakultas Peternakan dan Perikanan, Universitas Tadulako.

\section{Persiapan Sampel Ikan Uji}

Sampel ikan Nilem (O. hasselti) sebanyak \pm 30 ekor dikumpulkan dari danau Rano dalam bentuk basah, ditimbang dan dikeringkan di bawah sinar matahari tanpa dibersihkan. Selanjutnya sampel ikan dihaluskan menggunakan mesin penggiling. Sampel yang telah dihaluskan dianalisis proksimat untuk mengetahui kandungan nutriennya. Analisis dilakukan secara duplo untuk setiap parameter yang diamati.

\section{Uji Proksimat Sampel}

Uji proksimat pada sampel uji dilakukan dengan mengacu metode AOAC (2007). Kandungan sampel yang di analisis meliputi kadar air, protein kasar, lemak kasar, kadar abu, serat kasar dan karbohidrat.

Pengukuran kadar air sampel dilakukan dengan cara memanaskan cawan porselen dalam oven pada suhu $105^{\circ} \mathrm{C}$ selama 3 jam, didinginkan dalam desikator selama 30 menit lalu ditimbang bobotnya (P1). Sebanyak $5 \mathrm{~g}$ sampel dimasukkan dalam cawan porselin (S). Cawan porselin yang berisi sampel dipanaskan dalam oven dengan suhu $105^{\circ} \mathrm{C}$ selama 3 jam, setelahnya dimasukkan dalam desikator selama 30 menit kemudian dilakukan penimbangan (P2) hingga mendapatkan bobot tetap. Persentase kadar air dihitung dengan mengacu pada persamaan (1) yang digunakan oleh Miranti dan Putra (2019).

Kadar Air $(\%)=\frac{(P 1+S)-P 2}{S} \times 100 \ldots$

Pengukuran kadar abu dilakukan dengan cara menimbang cawan porselen yang telah dipanaskan dalam oven pada suhu $105^{\circ} \mathrm{C}$ selama 3 jam dan didinginkan selama 30 menit (P1). Selanjutnya sebanyak 2-3 g (S) dimasukkan dalam cawan porselen (S). Cawan yang berisi sampel diarangkan di atas pembakar hingga uapnya hilang, kemudian diabukan dalam tanur listrik pada suhu maksimum $550^{\circ} \mathrm{C}$ hingga pengabuan sempurna. Selanjutnya didinginkan dalam desikator dan ditimbang (P2). Persentase kadar abu dalam sampel dapat dihitung menggunakan persamaan (2).

$$
\operatorname{Kadar} A b u(\%)=\frac{(P 2-P 1)}{S} \times 100 \ldots
$$

Kadar lemak dari sampel uji ditentukan dengan menggunakan metode soxhlet. Dimana labu lemak terlebih dahulu dipanaskan dalam oven pada suhu $105^{\circ} \mathrm{C}$ selama \pm 2 jam, kemudian didinginkan dalam desikator selama \pm 30 menit dan ditimbang bobotnya (a gram). Sebanyak 5 gram (b gram) sampel dibungkus dengan kertas saring membentuk selongsong lemak, dimasukkan ke dalam labu lemak yang sebelumnya telah dikaitkan dengan kawat penyangga sebagai penahan saat ekstraksi berlangsung. Secara perlahan sebanyak 200 $\mathrm{mL}$ bahan pengekstrak $\mathrm{n}$-hexane dituangkan dalam labu lemak untuk proses pemanasan. Setelah dihubungkan dengan rangkaian listrik, dilakukan ekstraksi pada suhu 135$200{ }^{\circ} \mathrm{C}$ selama 5-6 jam. Evaporasi campuran lemak dan bahan pengekstrak hingga kering, kemudian labu lemak dimasukkan dalam oven pada suhu $105{ }^{\circ} \mathrm{C}$ dan didinginkan dalam desikator selama 30 menit, ditimbang (c gram) hingga beratnya konstan. Persentase 
KAUDERNI : Journal of Fisheries, Marine and Aquatic Science

https://jurnal.stplpalu.ac.id/index.php/kauderni/index

Volume 2, Nomor 2, (2020)

ISSN 2541-0571

https://doi.org/10.47384/kauderni.v2i2.44

kadar lemak dapat dihitung dengan persamaan (3).

$$
\text { Kadar Lemak }(\%)=\frac{c-a}{b} \times 100 \ldots
$$

Kadar serat kasar di analisis dengan cara memasukkan bag filter serat kedalam oven bersuhu $105{ }^{\circ} \mathrm{C}$ selama 1 jam, didinginkan dalam desikator selama 30 menit (hingga mencapai suhu ruang) dan ditimbang bobotnya (a gram). Sebanyak 1 gram (b gram) sampel yang telah dibebaskan lemaknya melalui metode ekstrasi soxhlet dengan pelarut $n$-hexane dimasukkan ke dalam bag filter, diatur dalam penyangga beaker glass, ditambahkan 250-300 mL $\mathrm{H}_{2} \mathrm{SO}_{4} 1,25 \%$. Selanjutnya beaker glass tersebut dipanaskan dan didinginkan, ditambahkan 250-300 mL NaOH 3,25\% dan di didihkan selama 30 menit. Selanjutnya bag filter berisikan residu diangkat dan dibilas menggunakan aquades panas, kemudian ditiriskan, dibilas dengan aseton dan dikering-anginkan hingga pelarut menguap. Kemudian dilakukan pengeringan dalam oven pada suhu $105^{\circ} \mathrm{C}$ selama $1 \mathrm{jam}$, dan didinginkan dalam desikator selama 30 menit. Selanjutnya dilakukan penimbangan bag filter berisikan residu sebagai (c gram) sampai berat konstan. Persamaan (4) yang digunakan untuk mengukur kadar serat kasar.

$$
\text { Serat } \operatorname{Kasar}(\%)=\frac{c-a}{b} \times 100 \ldots
$$

Pengukuran kadar protein dilakukan dengan metode Kjeldhal dengan tahapan digesti, distilasi dan titrasi. Tahap digesti dimulai dengan menimbang 1 gram sampel dan dimasukkan dalam tabung destruksi, ditambahkan 2 tablet kjehdahl (katalis). Sebanyak $20 \quad \mathrm{~mL} \quad \mathrm{H}_{2} \mathrm{SO}_{4} \quad$ (95-98\%) ditambahkan ke dalam tabung destruksi, didiamkan selama 10 menit dalam ruang asam sebelum di tempatkan pada alat destruksi (diggest). Destruksi di laksanakan pada suhu $410{ }^{\circ} \mathrm{C}$ selama \pm 2 jam (hingga larutan jernih), kemudian didinginkan pada suhu ruang dan ditambahkan $100 \mathrm{~mL}$ akuades. Selanjutnya dilakukan Tahap destilasi dan titrasi. Tahap ini dimulai dengan memasang tabung destilasi dan menghubungkan botol reagen yang telah diisi dengan $\mathrm{NaOH} 30 \%$, dan $\mathrm{H}_{3} \mathrm{BO}_{3} 2 \%$ yang mengandung indikator pada perangkat destilat. Selanjutnya destilat dari proses destilasi dikumpulkan dalam gelas kimia hingga volume mencapai $150 \mathrm{~mL}$ atau program alat berhenti secara otomatis. Destilat yang diperoleh dititrasi dengan HCL $0,1 \mathrm{~N}$ hingga terjadi perubahan warna. Selisih antara jumlah HCL $0,1 \mathrm{~N}$ sebelum dan setelah titrasi (Va). Selanjutnya hal yang sama dilakukan untuk blanko sebagai tahapan dalam pengerjaan sampel (Vb). Untuk menghitung kadar protein dalam bahan dapat menggunakan persamaan 5 sebagai berikut:

$$
\text { Kadar Protein }(\%) \frac{(V a-V b) \times M(H C l) \times 1 \times 14.007 \times 6.25}{(W \times 1000)} \times 100 \ldots(5)
$$

Metode dalam menghitung kadar karbohidrat mengacu pada persamaan yang digunakan oleh Miranti dan Putra (2019) yakni kadar karbohidrat ditentukan berdasarkan nilai bahan ekstrak tanpa nitrogen (BETN) kemudian ditambahkan kadar serat kasar (Persamaan 6).

$$
\begin{aligned}
& \text { BETN }=100-(\text { Kadar protein }+ \\
& \text { Kadar lemak }+ \text { Kadar serat kasar }+ \\
& \text { Kadar air }+ \text { Kadar abu })
\end{aligned}
$$

Kadar Karbohidrat (\%) $=$ BETN + Kadar serat kasar ...(6)

\section{Analisis Data}

Data hasil proksimat yang di dapatkan dianalisis secara deskriptif menggunakan program Microsoft Excel 2010 dan ditampilkan dalam bentuk gambar.

\section{HASIL DAN PEMBAHASAN}

Berdasarkan hasil analisis proksimat, kandungan dari tepung ikan Nilem $(O$. hasselti) dengan kadar air 9,36\% sebesar $39,62 \%$ protein, $1,4 \%$ lemak, $26,88 \%$ bahan ekstrak tanpa nitrogen (BETN), 17,9\% kadar abu dan 4,82 \% serat kasar (Gambar 1.). Kandungan nutrien tersebut (protein) tergolong tinggi dibandingkan yang dilaporkan oleh Balai Pengembangan dan 
KAUDERNI : Journal of Fisheries, Marine and Aquatic Science

https://jurnal.stplpalu.ac.id/index.php/kauderni/index

Volume 2, Nomor 2, (2020)

ISSN 2541-0571

https://doi.org/10.47384/kauderni.v2i2.44

Pengujian Mutu Hasil Perikanan (Utami et al. 2019) yakni sebesar $38,83 \%$ dengan kadar air sebesar 3,14\%. Sebaliknya, kandungan protein pada sampel uji lebih rendah dari hasil yang dilaporkan oleh Utami et al. (2019) yakni sebesar $15,95 \%$ dan kadar air $77,37 \%$ (ikan segar) yang setara jika dikonversi dalam bobot kering dengan persentase kadar air $10 \%$ adalah $62 \%$ protein. Kandungan protein yang lebih tinggi dari yang dilaporkan oleh Balai Pengembangan dan Pengujian Mutu Hasil Perikanan (Utami et al. 2019) terkait dengan kelimpahan makanan (Istadewi et al., 2016) dalam perairan dimana ikan uji berasal. Sedangkan kandungan protein yang lebih rendah dari hasil penelitian Utami et al. (2019) diduga karena tepung ikan sebagai sampel uji dibuat dari seluruh tubuh (full body) ikan tanpa ada yang dibuang, berbeda halnya pada sampel uji yang hanya dari bagian organ tertentu seperti daging tanpa sisik, jeroan dan kepala.

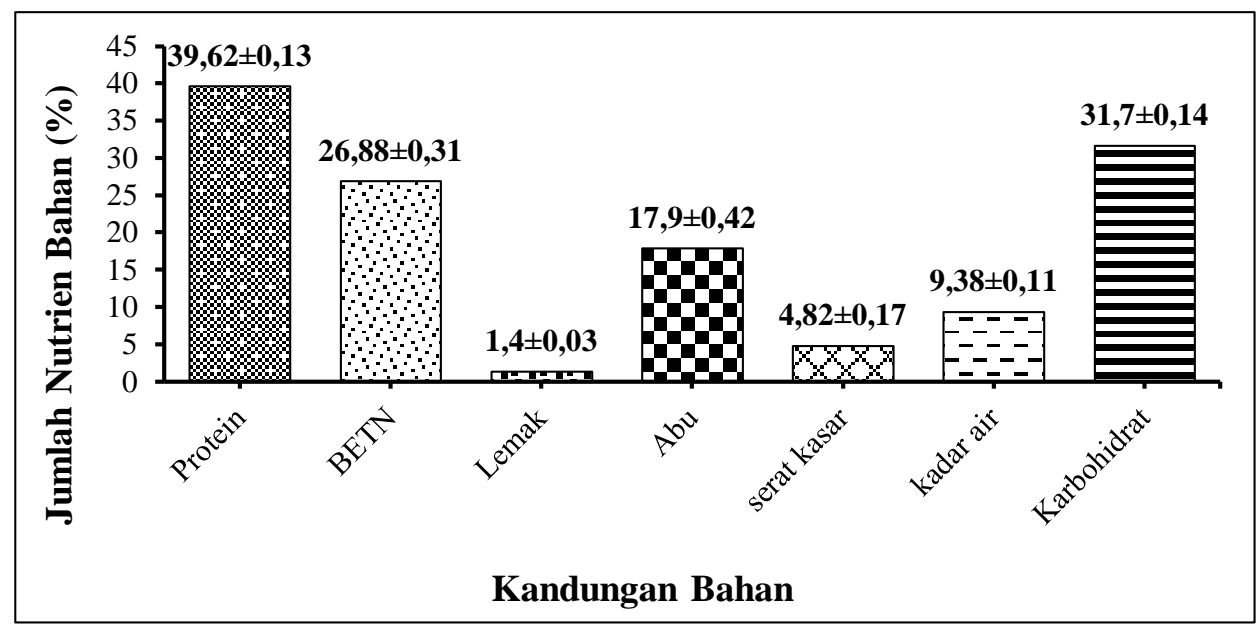

Gambar 1. Hasil analisis proksimat tepung ikan Nilem (O. hasselti).

Tinggi rendahnya kandungan protein dari suatu bahan sangat dipengaruhi oleh persentase dari komposisi bahan lainnya dalam sampel. Kandungan protein tepung ikan full body lebih tinggi dibandingkan tepung limbah ikan (kepala dan tulang) (Miranti dan Putra 2019), namun keduanya lebih rendah dari tepung ikan bagian daging tanpa sisik dan kepala (Utami et al., 2019) pada jenis ikan dan persentase kadar air yang sama. Selain itu, tinggi rendahnya kandungan nutrien (protein) pada ikan uji juga dipengaruhi oleh kelimpahan makanan dalam perairan dimana ikan tersebut hidup (Ramlah et al., 2016). Kandungan protein dari tepung ikan Nilem (O. hasselti) dalam penelitian ini masih tergolong rendah dibandingkan Standar Nasional Indonesia (SNI 2715 Tahun 2013) untuk kadar protein dalam tepung ikan sebagai bahan baku pakan yakni Mutu I, II dan III masing-masing minimal $60 \%, 55 \%$ dan $50 \%$.

Kadar lemak $(1,4 \%)$ dari tepung ikan Nilem (O. hasselti) uji lebih lendah dibandingkan hasil penelitian Utami et al. (2019) yakni 17,30\%, dan kadar abu (5,25\%) (persentase kadar air 10\%) lebih rendah dari penelitian ini (17,9\%; kadar air 9,36\%).

Kandungan lemak yang rendah pada ikan uji disebabkan adanya proses pengeringan sebelum pengujian sehingga kandungan lemak pada sampel uji diduga berkurang seperti halnya dengan kandungan air. Hal ini sejalan yang dikemukakan oleh Handoyo dan Assadad (2016) bahwa kadar lemak dari bahan baku pakan dapat dikurangi melalui pengepresan termasuk pengeringan melalui penirisan. Sedangkan kadar abu yang tinggi dalam sampel uji disebabkan oleh jenis bahan baku yang digunakan, yakni tanpa dibersihkan dari sisik dan tulang (full body) 
(Gambar 2). Hal ini sesuai yang dikemukakan oleh Sudarmadji et al. (2007); Handoyo dan Assadad (2016) bahwa tinggi rendahnya kadar abu dalam suatu bahan dipengaruhi oleh jenis bahan, waktu dan suhu yang digunakan dalam proses pengeringan. Tepung ikan berbahan full body tentunya memiliki kadar abu yang lebih tinggi dibandingkan dari bahan daging ikan. Selanjutnya, semakin lama waktu dan semakin tinggi suhu pengeringan menyebabkan kadar air dari sampel semakin berkurang dan kadar abu semakin meningkat. Namun kadar lemak dan Abu dari sampel uji dalam penelitian ini masih sesuai dalam standar baku mutu I untuk tepung ikan sebagai bahan baku pakan (SNI 2715 tahun 2013).

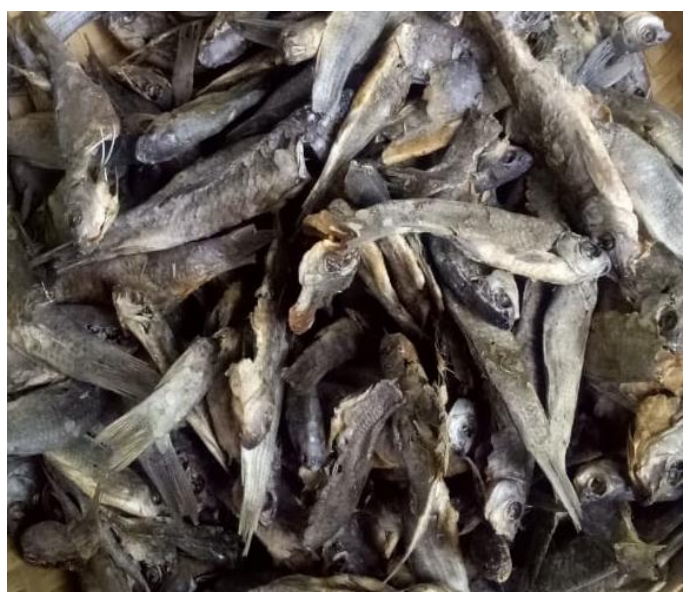

Gambar 2. Tampilan ikan Nilem $(O$. hasselti) full body Pasca Pengeringan

Selanjutnya Akumulasi dari nilai serat kasar dan bahan ekstrak tanpa nitrogen (BETN) yang digambarkan sebagai karbohidrat sebesar 31,7 \%. Kandungan karbohidrat da dengan kandungan air yang rendah secara langsung akan mempengaruhi peningkatan kandungan nutrien lain bahan termasuk karbohidrat (Muchtadi dan Ayustaningwarno, 2010; Riansyah et al.., 2013).

\section{KESIMPULAN}

Tepung Ikan nilem (O. hasselti) memiliki kandungan nutrien mencakup protein, lemak, karbohidrat (BETN dan serat kasar), kadar abu masing masing sebesar
$39,62 \%, 1,4 \%, 31,7 \%, 17,9 \%$ dengan kadar air $9,38 \%$. Persentase dari kandungan nutrien tepung ikan nilem tidak memenuhi standar baku mutu (I, II dan III) tepung ikan dari segi kandungan protein sehingga hanya potensial sebagai bahan subtitusi bahan baku utama sebagai sumber protein hewani.

\section{UCAPAN TERIMA KASIH}

Terima kasih kepada Universitas Tadulako yang telah memfasilitasi terlaksananya penelitian ini melalui dana DIPA Fakultas Peternakan dan Perikanan Tahun 2020.

\section{REFERENSI}

AOAC [Association of Official Analytical Chemists]. 2007. Official Methods of Analysis, $18^{\text {th }}$ edition, $2^{\text {nd }}$ revision. AOAC International, Gaithersburg, Maryland. USA. $2451 \mathrm{pp}$.

Gani, A., J. Nilawati dan A. Rizal. 2015. Studi habitat dan Kebiasaan makanan (food habit) ikan rono Lindu (Oryzias sarasinorum Popta, 1905). Jurnal Sains dan Teknologi Tadulako. 4(3): 918.

Handoyo, E. T. dan L. Assadad. 2016. Karakterisasi Proses Produksi dan Kualitas Tepung Ikan di Beberapa Pengelolah Skala Kecil. Seminar Nasional Tahunan XIII Hasil Perikanan dan Kelautan. Hal. 197205.

Herjayanto, M., A. Gani, Y. S Adel dan N. Suhendra. 2019. Freshwater fish of lakes and it's inlet rivers in Sulawesi Tengah Province, Indonesia. Journal of Aquatropica Asia. 4(1): 1-9.

Istadewi, I., M. Jamhari dan I. N. Kundera. 2016. Kelimpahan Plankton di Danau Rano Kecamatan Balaesang Tanjung dan Pengembangannya Sebagai Media Pembelajaran. Jurnal Sains dan Teknologi Tadulako. 5 (3): 75-84.

Miranti, S. dan W. K. A. Putra. 2019. Uji Potensi Limbah Ikan dari Pasar Tradisional di Kota Tanjung Pinang sebagai Bahan Baku Alternatif Pembuatan Pakan untuk Budidaya Ikan Laut. Intek Akuakultur. 3(1): 8-15. 
KAUDERNI : Journal of Fisheries, Marine and Aquatic Science

https://jurnal.stplpalu.ac.id/index.php/kauderni/index

Volume 2, Nomor 2, (2020)

ISSN 2541-0571

https://doi.org/10.47384/kauderni.v2i2.44

Muchtadi, T. R dan F. Ayustaningwarno. 2010. Teknologi Proses Pengolahan Pangan. Alfabeta. Bandung.

Paino, C. 2015. Rano, Danau Sejuta Harapan Masyarakat Balaesang Tanjung yang Diusik Tambang. Mongabay, Situs BeritaLingkungan.[https://www.mong abay.co.id/2015/07/25/rano-danausejuta-harapan-masyarakat-balaesangtimur-yang-diusik-tambang/].

Ramlah, E., Z. Soekendarsi, Hasyim dan M.S. Hasan. 2016. Perbandingan Kandungan Gisi Ikan Nila Oreochromis niloticus Asal Danau Mawang Kabupaten Gowa dan Danau Universitas Hasanuddin Kota Makassar. Jurnal Biologi Makassar (Bioma). 1(1): 39-46.

Riansyah, A., A. Supriadi dan R. Nopianti. 2013. Perbedaan Suhu dan Waktu Pengeringan Terhadap karakteristik Ikan Asin Sepat Siam (Trichogaster pectoralis) dengan Menggunakan Oven. Fishtech. II(1): 53-68

SNI 2715 [Standar Nasional Indonesia]. 2013. Tepung Ikan Bahan Baku pakan . Badan Standar Nasional. Jakarta.

Sudarmadji, S., B. Haryono dan Suhardi. 2007. Analisa Bahan Makanan dan Pertanian. Liberty. Yogyakarta.

Takeuchi, T. 1988. Laboratory work-cheical evaluation of dietary nutrients. In: Fish Nutrition and Mariculture (ed. by T. Watanabe). Kanagawa International Fisheries Training Center, Japan International Cooperation Agency, Kanagawa. Hal. 179-233.

Umar, C. dan P. S. Sulaiman. 2013. Status Introduksi Ikan dan Strategi Pelaksanaan Secara Berkelanjutan di Perairan Umum Daratan di Indonesia. Jurnal Kebijakan Perikanan Indonesia. 5 (2):113-120.

Utami, D. P., E. Rochima, R. I. Iskandar dan Pratama. 2019. Perubahan Karakteristik Ikan Nilem Pada Berbagai Pengolahan Suhu Tinggi. Jurnal Perikanan dan Kelautan. 10 (1): 39-45. 